\title{
Sustainable smart specialisation of small-island tourism countries
}

\author{
Korak Bhaduri and Shivendra Pandey
}

\begin{abstract}
Purpose - The purpose of this paper is to investigate the impact of information and communication technology (ICT) development and terrestrial and marine protection on the economic and environmental sustainability of small-island tourism countries. The current study expands the smart specialisation literature in the context of small-island tourism nations. It also proposes sustainable future growth strategies for these countries.
\end{abstract}

Design/methodology/approach - This paper adopted structural equation modelling using the data of 14 island nations between 1995 and 2014. The selection of countries was based on a set of criteria borrowed from literature.

Findings - The results indicate that the development of ICT infrastructure was not only associated with a higher inflow of tourists and a higher GDP per capita but also with a higher carbon dioxide $\left(\mathrm{CO}_{2}\right)$ emission. Results also suggest that higher protection of terrestrial and marine areas has no impact on tourist inflows in tourism countries. Also, higher protection decreases the dependence of the total output on the tourism sector.

Research limitations/implications - A limitation of this study is the lack of available macro data on some other relevant variables for the countries studied.

Social implications - Following the findings of this study, the governments of these countries should make stringent environmental regulations and relax the telecom regulations for sustainable smart specialisation.

Originality/value - This study presents a novel insight into the sustainability challenge of island nations through the lens of smart specialisation. It also contributes to the literature on ICT and development.

Keywords Sustainability, Technology, Tourism, ICT, Island nations, Smart specialization

Paper type Research paper

\section{Introduction}

Regions develop competitive advantages in specific industrial sectors due to a confluence of factors such as the availability of natural resources, proximity to markets and high regional or international demands (Camagni, 2017). Some noteworthy regional specialisations include the fashion and textile industry in Tuscany, Italy, or the automobile hub in Michigan, USA. Thus, growth strategies often rely on exploiting a range of local technological, social, cultural, natural or creative assets. This concept is called "smart specialisation" in the literature, which first gained popularity in Europe, followed by OECD countries (Foray et al., 2009; McCann and Ortega-Argilés, 2015). Many states, especially small-island nations, have smartly specialised as tourist destinations. These small-island nations are home to the most diverse, unique and vulnerable ecosystems of the world. Approximately one-tenth of the world population lives in islands whose livelihood and wellbeing depend on the sustainable use of the insular biodiversity[1]. However, adopting a tourism-led growth strategy based on natural resources leads to their depletion and makes the strategy unsustainable in the long run.

Sustainable development is defined as "the development that meets the needs of the present without compromising the ability of future generations to meet their own needs". The study of
Korak Bhaduri and

Shivendra Pandey are both based at the Indian Institute of Management Rohtak, Rohtak, India.

Received 30 January 2019 Revised 29 May 2019 Accepted 5 August 2019

(c) Korak Bhaduri and Shivendra Pandey. Published in Journal of Tourism Futures. Published by Emerald Publishing Limited. This article is published under the Creative Commons Attribution (CC BY 4.0) licence. Anyone may reproduce, distribute, translate and create derivative works of this article (for both commercial and non-commercial purposes), subject to full attribution to the original publication and authors. The full terms of this licence may be seen at http://creativecommons.org/licences/by/4.0/ legalcode 
the sustainability of smart tourism specialisation of small islands is vital because of two reasons. First, the development of these countries depends on tourism (Hugo and Nyaupane, 2016; Telfer and Sharpley, 2015). Second, the tourism industry itself depends on the natural environment. As Lane (2001) argued, sustainable tourism is not designed to end tourism, but to cater to the "interests of all three parties involved - the host habitats and communities, the tourists, and the industry itself". Sustainable tourism seeks a balance between conservation and development. This trade-off between human well-being and ecological sustainability or the simultaneous exploitation and protection of resources has been called as the "environmental paradox" in the literature (Romão and Nijkamp, 2017).

Countries with high tourism specialisation, defined by the share of international tourism receipts to GDP, were found to share a unique characteristic - they were all small (Lanza and Pigliaru, 2000). These countries were found to economically outperform other small or comparable countries such as oil-producing countries, small countries or least developed countries (Brau et al., 2003, 2007). It is important to study the sustainability of such economies with overdependence on tourism.

Based on panel data of small-island nations between 1995 and 2014, the present study addresses the following question: how does enhancement in territorial capital impact economic and environmental sustainability of small-island tourism nations? For this study, two components of territorial capital, namely, information and communication technology (ICT) development and terrestrial/marine protection, were considered. Terrestrial and marine protection was used, as it is the most precious resource in island nations. ICT was included for its role in travel decision making and facilitation. The model also examines how territorial capital affects demand- and supply-side tourism specialisations. The present research also examines how tourism specialisation impacts sustainability. In the following section, we discuss the theoretical framework and develop hypotheses. Next, we discuss the methodology used for the study. Results and discussions follow the methodology section. Then, we explain the theoretical contributions and some policy implications of our study. Finally, we conclude, discussing some limitations and future scope of our study.

\section{Theoretical framework and hypotheses development}

A destination's tourism competitiveness depends on a multitude of resources and factors. Smart specialisation utilises place-specific unique resources to achieve competitive advantage. Innovative strategies making optimal utilisation of these resources produce the best economic outcomes. For this study, we use two variables to represent the territorial capital of the island nations - territorial and marine protection, and ICT development. According to the World Bank:

\footnotetext{
Terrestrial protected areas are totally or partially protected areas of at least 1,000 hectares that are designated by national authorities as scientific reserves with limited public access, national parks, natural monuments, nature reserves or wildlife sanctuaries, protected landscapes, and areas managed mainly for sustainable use. Marine protected areas are areas of intertidal or subtidal terrain-and overlying water and associated flora and fauna and historical and cultural features - that have been reserved by law or other effective means to protect part or all of the enclosed environment.
}

The terrestrial and marine areas constitute the core attractors for tourists in an island nation. Protecting these areas gives them time for replenishment and ensures their ecological balance. The abundance of such attractors supported by key infrastructure enhances the destination's tourism competitiveness.

One of the vital infrastructural assets for sustainable tourism is ICT. ICT has been identified to service sustainability through several approaches such as Green ICT and Environmental Informatics (Hilty et al., 2011). Benefits of ICT usage include higher access to information, lower cost of production, removal of specific geographical barriers and higher transparency 
(Shanker, 2008). Tourism is a combination of multiple interrelated industries. ICT usage has thoroughly transformed it through facilities like online reservation, information search through various online platforms and social media, more flexible and customised service offerings and integrated customer management services and supply chain management (Bethapudi, 2013). ICT has also contributed to improved visa procedures (UNWTO, 2017) and better travel facilitation. Easier travel facilitation leads to increased demand, job creation and international understanding, which, in turn, generates overall export-oriented economic development.

Moreover, sustainable development through "smart tourism" (Gretzel et al., 2015) may arise when other relevant economic sectors of a region contribute to add value to tourism. The contribution to tourism by related industries calls for a high inter-linkage among these sectors. Here, ICT contributes to knowledge and innovation spillovers into smart tourism products and services experience (Romão and Neuts, 2017). In essence, ICT acts as a confidence booster and information source for tourists, and it helps them ultimately decide the destination for a visit. ICT assists the firms to reach a wider global audience, and the ultimate decision relies more on the available information than the destination itself (Hsu and Li, 2016; Park and Jang, 2013).

H1 links components of territorial capital, ICT, and terrestrial and marine protection, to demand side of tourism specialisation, that is the arrival of tourists. Both ICT development, represented by mobile users, and the percentage of terrestrial and marine protection are hypothesised to have positive impacts on international tourism arrival.

Destination competitiveness literature also suggests that inputs in the form of territorial capital endowments or research and development expenses determine the output of tourism supply specialisation. Unique products and services of destinations provide highquality offerings while ensuring resource preservation (Buhalis, 1999; Kozak, 1999; Page and Dowling, 2002; Romão and Neuts, 2017). H2 relates a country's territorial capital with the supply side of tourism specialisation. The share of tourism receipts to GDP represents the supply-side tourism specialisation of a country. The higher the territorial capital measured by mobile usage or terrestrial and marine protection, the higher is the expected contribution of the tourism sector to the overall GDP.

McElroy and de Albuquerque (1991) identified five dimensions in which an economy excessively dependent on exploitative tourism of a fragile ecosystem renders itself structurally dysfunctional. First, international tourism leads to resource imbalances in fragile island ecosystems, as the commercialisation of their pristine water and mountain resources alters the critical habitats. Second, the wastes generated over time outpace the fragile ecosystem's absorptive capacity. Third, tourism's seasonality contributes to system overload. The short peak season encourages extensive small-scale activities to extract income from the limited demand. This is followed by a slack period of the off season. Recurring cycles of unemployment in the slack season develop intense year-round tourism pressure in the long run, which, in turn, denies the ecosystem time for self-renewal. Fourth, as explained by Holder (1988), island decision makers' growth bias is reflected in their focus on increasing arrivals over net visitor expenditure. Finally, the profit orientation of the sector, mainly airlines, hotels and tour operators, drives the tourism economy to expand tourist densities beyond the island's ecological and social carrying capacity. Moreover, the tourism sector, primarily through tourist transportation, is found to be excessively contributing to the emission of greenhouse gases (UNWTO, 2017). Hence, the higher arrival of international tourists or tourism demand is expected to contribute to environmental pollution.

Tourism is one of the strategic sectors identified as a potential growth driver poised to reduce rural-urban gap (McCann and Ortega-Argilés, 2015). International tourism accounts for 7 per cent of the world's goods and services exports in 2017, making it the third-largest export category (UNWTO, 2017). It is growing faster than world trade in the last five years. Unsurprisingly, tourism-led growth literature is saturated with a positive association between 
higher tourism and economic growth due to higher exports. The tourism sector is found to have a poverty-alleviating and multiplier effect on the economy (Adamou and Clerides, 2010; Davidson and Sahli, 2015; Rogerson, 2013). Consequently, small-island tourism countries economically outperformed other similar countries (Brau et al., 2003, 2007). Hence, $\mathrm{H} 3 \mathrm{a}-\mathrm{H} 3 \mathrm{~b}$ can be formulated, as shown in Figure 1. The higher the arrival of tourists in a country, the higher are the expected $\mathrm{CO}_{2}$ emissions and per capita GDP.

Romão and Neuts (2017) found that regions with high tourism specialisation displayed poor socio-economic performance and relatively less $\mathrm{CO}_{2}$ emissions, that is lower environmental pollution. This is because a higher share of tourism in the total value added implies a lower development of other top polluting sectors such as manufacturing. Therefore, $\beta$ coefficients in $\mathrm{H} 4 \mathrm{a}-\mathrm{H} 4 \mathrm{~b}$, relating high share of tourism in value added with sustainability indicators, are expected to be negative, that is the higher the share of the tourism sector in the total value added, the lower are the expected per capita income and $\mathrm{CO}_{2}$ emissions.

H5 relates the supply- and demand-side specialisations of the tourism sector. The higher the supply-side specialisation, the higher is the expected demand-side specialisation. In other words, if the tourism sector has a higher share of the total value added, then more international tourists are expected to arrive.

Nature-based tourism emphasises environmental protection for stable socio-economic development (Neto, 2003), that is higher territorial and marine protection is expected to lead to a sustainable economic growth. However, this development comes at the cost of emissions resulting from developing other capital-intensive sectors. There is extant literature on the role of ICT, the other territorial capital indicator, in development, especially for the developing world and in addressing the digital divide (Avgerou, 1998, 2008; Sassi and Goaied, 2013). Hence, higher ICT or mobile usage is expected to lead to higher economic development, as well as $\mathrm{CO}_{2}$ emissions. $\mathrm{H} 6$ is formulated, as shown in Figure 1. The higher the aspects of territorial capital, the higher are the expected GDP per capita and $\mathrm{CO}_{2}$ emissions.

\section{Data and methodology}

The empirical analysis was done on secondary data from the World Bank on 14 countries. We borrowed Brau et al.' s (2007) selection of 14 "tourism countries" for our analysis, which,

\section{Figure 1 Structural framework}

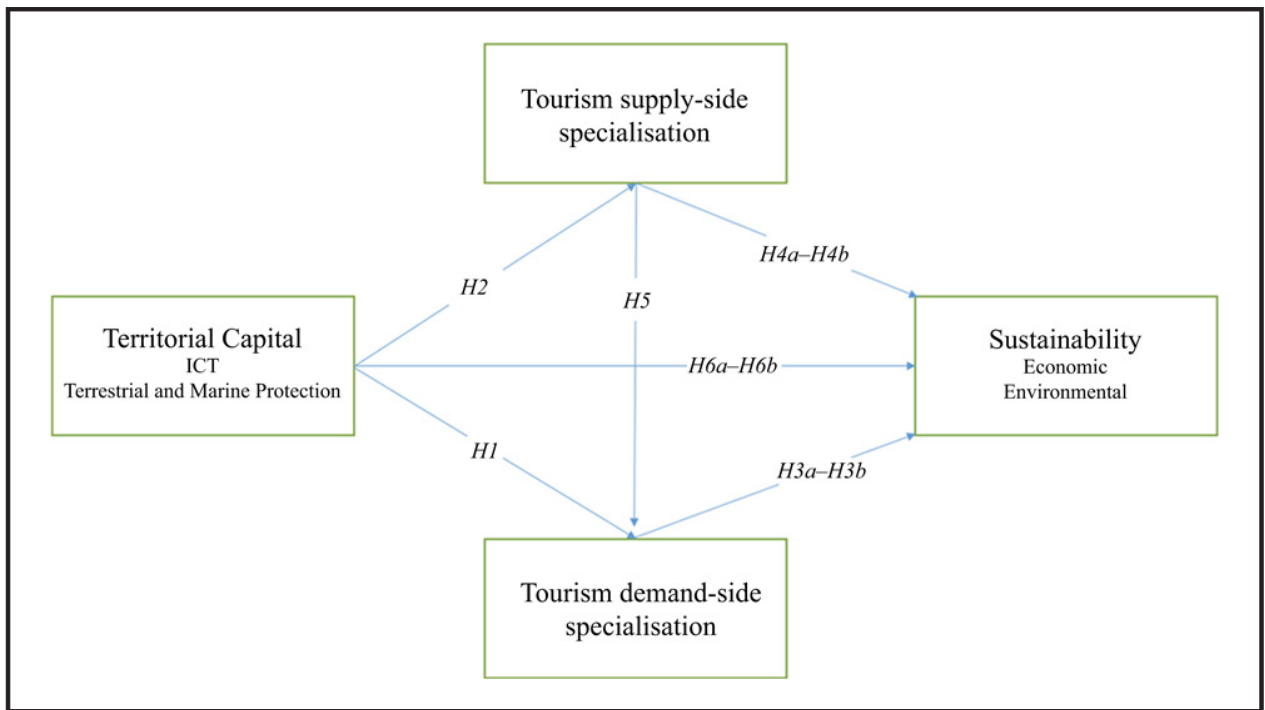


in turn, followed from Easterly and Kraay (2000). A tourism country is defined in the study of Brau et al. (2007) as one with higher than 10 per cent average tourism specialisation over the period 1980-2003. The tourism specialisation is measured as international tourism receipts (current US\$) per current US\$ GDP. For the analysis, the following 14 countries are considered: The Bahamas, Barbados, Bermuda, Cyprus, Fiji, Grenada, Maldives, Malta, Samoa, Seychelles, St Kitts and Nevis, St Lucia, St Vincent and Grenadines, and Vanuatu. These countries do not belong to the category of resource-rich developing countries as per IMF (Ghura and Pattillo, 2012), that is countries with at least 20 per cent of exports from natural resources like oil/gas, minerals, precious stones and metals. Hence, these countries belong to the set of tourism resource-rich countries. For the periods 1980-95 and 1980-2003, Brau et al. (2003) and Brau et al. (2007), respectively, found that tourism countries grow much faster than similar smaller nations without tourism specialisation, that is tourism and smallness together are highly conducive for growth. The period of analysis for the current study is 1995-2014. Figure 2 shows the tourism specialisation of the selected countries for the period 1995-2014. The dashed line indicates the cut-off value of 10 per cent receipts from tourism as a share of GDP.

\subsection{Variables}

In this study, six variables (see Table Al for details) were taken, with two variables indicating each of the following: territorial capital, tourism specialisation and sustainable development. Emphasising on smart specialisation, the variable "Mobile cellular subscriptions (per 100

\section{Figure 2 Supply-side tourism specialisation}

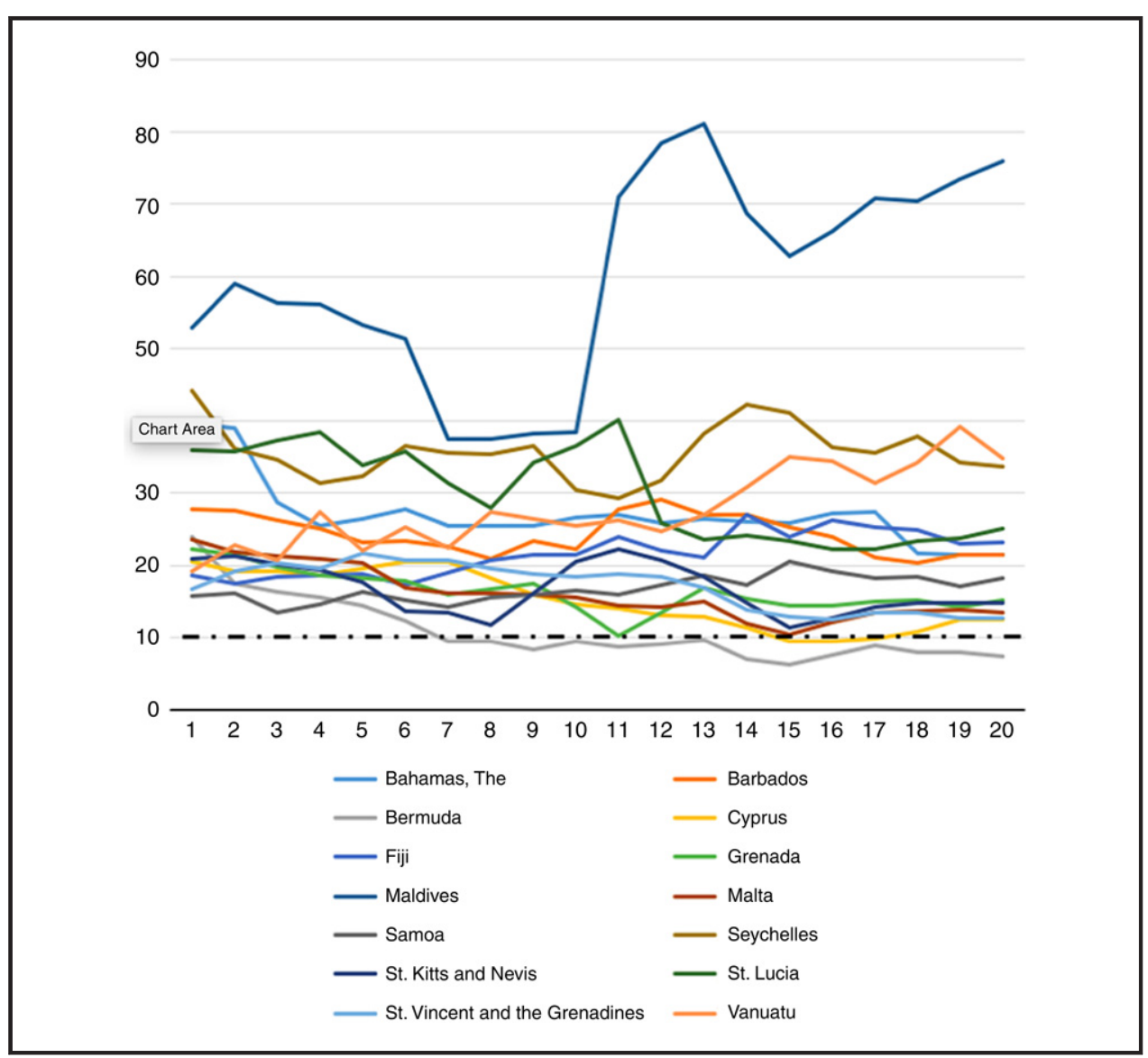


people)" was used to represent territorial resources or territorial capital, that is ICT development as a component of "material assets of the territory", in particular (Romão and Neuts, 2017). Mobile usage is a reliable indicator of the evolution of ICT usage in a country. Besides, "Terrestrial and marine protected areas (\% of total territorial area)" also represents territorial capital. Tourism specialisation is identified by the following variables: the ratio of international tourism receipts to GDP and the number of international tourism arrivals. Finally, the economic and environmental sustainability indicators are measured using the variables GDP per capita at current prices and $\mathrm{CO}_{2}$ emissions (metric tons per capita), respectively. We take the natural log of the following variables: the number of international tourist arrivals and GDP per capita at current prices.

\subsection{Structural equation modelling (SEM)}

SEM allows the researcher to model relationships between several criterion and predictor variables. Multiple regression equations can be estimated simultaneously using SEM. Figure 1 provides an overview of the hypothesised relational model. Both the endogenous variables of sustainability, that is GDP per capita and $\mathrm{CO}_{2}$ emissions, have both direct and indirect impacts.

Following Romão and Neuts (2017), here, Mulaik and Millsap's (2000) four-stage modelling was reduced to a two-stage approach for the path analyses. The first two steps, that is explanatory factor analysis and confirmatory measurement model, are impertinent, owing to the absence of latent constructs. Hence, we run the third and fourth steps, that is relational structural model and the nested models, for the estimations. This two-step approach allows us to estimate the paths by identifying the most parsimonious model.

The hypotheses can be empirically specified in the form of simple equations. H1, for instance, can be written as follows:

$$
\ln (\text { tour_arr })=\beta_{\ln \left(t o u r \_a r r\right), \text { mobile_users }} \text { mobile_users }+\beta_{\operatorname{In}(\text { tour_arr }), T e r \_m a r} \text { Ter_mar }+u
$$

Here, $\beta$ refers to direct effects. $H 2$ can similarly be represented as $H 1$ where both the $\beta$ coefficients are expected to be positive:

$$
\text { rcpts_by_gdp }=\beta_{\text {rcpts_by_gdp,mobile_users }} \text { mobile_users }+\beta_{\text {rcpts_by_gdp,Ter_mar Ter_mar }}+u
$$

The equation of GDP per capita can be expressed as follows:

$$
\begin{aligned}
& \ln (G D P p c)=\beta_{\ln (G D P p c), \text { mobile_users }} \text { mobile_users }+\beta_{\ln (G D P p c), T e r \_m a r} \text { Ter_mar } \\
& +\beta_{\ln (G D P p C), \ln \left(t o u r_{a} a r r\right)} \ln (\text { tour_arr })+\beta_{\ln (G D P p C), r c p t s \_b y \_g d p} r c p t s_{-} b y \_g d p+v
\end{aligned}
$$

The aggregate effect of mobile_users on GDPpc, for instance, would comprise the direct

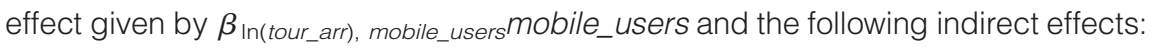

$$
\begin{aligned}
& \beta_{\text {rcpts_by_gdp,mobile_users }} \\
& \times\left[\beta_{\ln (G D P p c), r c p t s_{-} b y \_g a p}+\left(\beta_{\ln (\text { tour_arr }), r c p t s_{-} b y \_g d p} \times \beta_{\ln (G D P p c), \ln (\text { tour_arr })}\right)\right], \\
& \beta_{\ln (\text { tour_arr }), \text { mobile_users }} \times \beta_{\ln (G D P p c), \operatorname{In}(\text { tour_arr })} .
\end{aligned}
$$

Maximum likelihood parameter estimation was used to test these paths.

\section{Results and discussions}

Satisfactory goodness-of-fit indicators were obtained on running the model (Tables I). A $\chi^{2}$ statistic of 2.46 was obtained, with a $p$-value of $0.1167(\mathrm{df}=1)$, suggesting a good model 


\section{Table I Fit indices of model}

CMIN/DF

TLI

SRMR

0.0257

RMSEA

0.072

HOELTER (0.05)

436

HOELTER (0.01)

fit. As discussed by Hooper et al. (2008), there are alternate statistical measures of model fit. The obtained root-mean-square error of approximation (RMSEA) of 0.072 , comparative fit index (CFI) of 0.998, Tucker-Lewis Index (TLI) of 0.975, standardized root mean square residual (SRMR) of 0.0257 and HOELTER value of 753 at a significance of 1 per cent indicate that there is an acceptable fit of the model into the data. The obtained relationships are presented in Table II.

The best-fitting model was obtained by testing several nested structural models. Comparisons by CFI values and $\chi^{2}$ values, incorporating different degrees of freedoms, indicated that the original model was the best acceptable model based on the grounds of parsimony (Garson, 2015). An error covariance between $\mathrm{CO}_{2}$ emissions and per capita GDP was drawn to account for the common unobserved factors affecting both $\mathrm{CO}_{2}$ emissions and per capita GDP like population growth, income distribution, etc. (Holtz-Eakin and Selden, 1995)

Results indicated that higher usage of mobile phones is positively correlated with a higher per capita GDP. This result is as per the ICT literature (e.g. Piatkowski, 2004; Sassi and Goaied, 2013). Similarly, areas with high $\mathrm{CO}_{2}$ emissions are also those with high mobile usage. High mobile usage similarly leads to high tourism arrival. This is possibly due to the better availability of information to tourists and easier travel facilitation, as discussed earlier, which influence the final decision of destination made. However, mobile usage was found not to be significantly correlated with receipts from tourism as a fraction of the GDP. This may be because usage of mobiles may have a lagged effect on the supply-side tourism specialisation measured by receipts by GDP, which is not captured in the model. These results indicate that in the context of small tourism countries, ICT development does not correlate with contemporary supply-side tourism specialisation, but it has a significant positive correlation with contemporary demand-side tourism specialisation, that is the arrival of international tourists.

\section{Table II Results of structural model}

\begin{tabular}{|c|c|c|c|}
\hline Hypothesis & Estimate & $p$-value & Remarks \\
\hline mobile_users $\rightarrow$ rcpts_by_gdp & 0.000 & 0.405 & Not supported \\
\hline Ter_mar $\rightarrow$ rcpts_by_gdp & -0.023 & 0.000 & Supported \\
\hline mobile_users $\rightarrow$ In_tour_arr & 0.005 & 0.000 & Supported \\
\hline Ter_mar $\rightarrow$ In_tour_arr & 0.074 & 0.149 & Not supported \\
\hline rcpts_by_gdp $\rightarrow$ In_tour_arr & 1.077 & 0.038 & Supported \\
\hline mobile_users $\rightarrow$ In_GDPpc & 0.007 & 0.000 & Supported \\
\hline mobile_users $\rightarrow \mathrm{CO}_{2}$ & 0.009 & 0.000 & Supported \\
\hline Ter_mar $\rightarrow$ In_GDPpc & 0.297 & 0.000 & Supported \\
\hline Ter_mar $\rightarrow \mathrm{CO}_{2}$ & 0.718 & 0.000 & Supported \\
\hline In_tour_arr $\rightarrow$ In_GDPpC & 0.387 & 0.000 & Supported \\
\hline In_tour_arr $\rightarrow \mathrm{CO}_{2}$ & 1.064 & 0.000 & Supported \\
\hline rcpts_by_gdp $\rightarrow$ In_GDPpc & -2.078 & 0.000 & Supported \\
\hline rcpts_by_gdp $\rightarrow \mathrm{CO}_{2}$ & -4.205 & 0.000 & Supported \\
\hline
\end{tabular}


Terrestrial and marine protection did not correlate with tourism demand measured by tourism arrival. This implies that national protection or restriction of terrestrial and marine resources does not influence visitors' inflow. This may be due to the low percentage of areas under protection. The island nations are treasures of nature's flora and fauna, and a mean protection of 0.766 per cent still leaves an abundance of nature's grandeur for tourists to explore. As a result, the increased burden on the ecosystem may make tourism unsustainable. Protection, however, has a significant negative correlation with the contribution of the tourism sector to GDP. This again is a positive indication for the economy. Higher protection will lead to less dependence on tourism, which, in turn, will lead policymakers to focus on other sectors, thereby leading to a more inclusive growth.

A more specialised supply-side tourism sector has significant and negative correlations with both the variables, $\mathrm{CO}_{2}$ emissions and per capita income. Upon comparing small tourism countries with other country groups like oil-producing countries, OECD countries or other small countries, Brau et al. (2003) found that small tourism countries outperformed economically for the period 1980-1995. This happened because of several factors like fluctuating oil prices in the period, higher trade openness in tourism countries, etc. Results of our study for the period 1995-2014, however, contradict their findings. Here, we find that specialising in the tourism sector may not be economically sustainable, and it may adversely affect the per capita income. Higher specialisation was associated with lower income levels; hence, it called for the development of other sectors. Despite being environmentally sustainable, high dependence on tourism may not be economically viable for the small tourism countries in the long run.

A more specialized demand-side tourism sector significantly and positively impacts both $\mathrm{CO}_{2}$ emissions and the per capita income. Hence, higher tourist arrival may be leading to higher income, but it is damaging the ecosystem. This suggests the need for smart regional specialisation and eco or green tourism.

The supply-side specialisation has a positive and significant, 5 per cent, impact on demand-side tourism specialisation. This highlights the interdependence of both (Figure 3).

\section{Theoretical contributions}

The main theoretical contribution of this paper lies in its focus on an under-researched area of sustainable development of small-island economies. This area of study is important because of the critical role that island ecology plays in indicating global environmental

\section{Figure 3 Structural model evaluation}

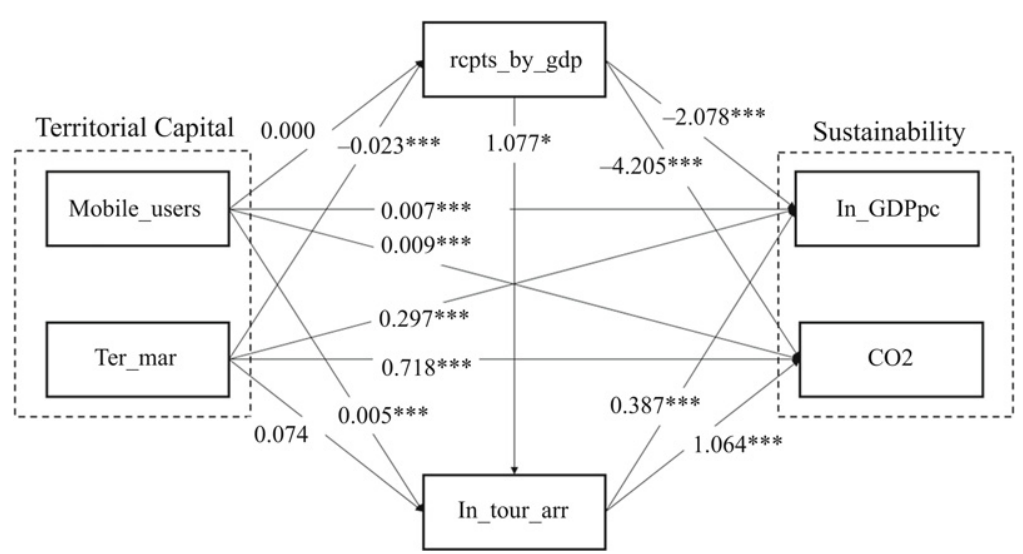


health, as well as the size of the human population that is supported by these tourism-led island economies. The theoretical underpinning of this paper is the recently introduced concept of smart specialisation. Although some previous studies discussed the role of local territorial resources in formulation of growth strategies, these studies are mostly in the context of developed countries. This paper is novel in integrating smart specialisation into the tourism-led growth strategy of small-island nations.

Further, this paper also contributes to the growing literature on ICT and development. This literature body assumes that ICT infrastructure contributes to the socio-economic development of developing countries. The current paper empirically validates this premise.

\section{Policy implications}

High dependence on tourism makes its volatility a significant concern in small-island states or developing countries. Reductions or fluctuations in tourism demand have serious employment implications and may generate more poverty (UNWTO, 2017). It is crucial for policymakers to target stability and sustainability of this sector. As is evident from the study, in small-island nations, ICT plays a key role in attaining higher tourism specialisation as well as in ensuring its sustainability. This study has several policy implications in the context of small-island tourism economies. First, a higher focus on ICT development is necessary for both the development of the tourism sector as well as the other related sectors. Telecom regulation is a significant policy area for governments worldwide. Discounts on licencing fees, universal service obligation funds, spectrum usage charges and other taxes levied by the telecom regulator might be necessary for rapid progress in information sciences in developing and small countries. Telecom industry plays a pivotal role in the growth and development of all other sectors, especially tourism, in addition to being a revenue generator itself.

Second, our study found that higher terrestrial and marine protection is not only necessary for the environmental sustainability of the island ecosystems, but it may also lead to the prosperity of other sectors of the economy and hence less dependence on tourism. The mean percentage of protected areas in our set of small-island nations, 0.766 per cent, is abysmally lower than the world average, 12.807 per cent, in 2014. Acknowledging this plight, several new sites, especially marine, have been designated as protected areas in recent years. In 2017, nearly $7 \mathrm{~m}$ square kilometres of protected area was added to the World Database on Protected Areas, which included two of the world's largest protected areas - Ross Sea Region in Antarctica and Marae Moana Marine Park in Cook Islands (XXXX, 2018). Higher protection in conjunction with local awareness and support would be necessary to meet the Aichi Biodiversity Targets as well as the local economic goals. Poverty reduction strategies must be built around disincentives for activities threatening the future of biodiversity like overfishing. Dumping anthropogenic wastes into water bodies must be checked.

Third, governments and private players should focus more on green tourism based on regional strengths and merits. Key areas for innovation can be alternative energy sources, public transport systems, waste disposal and recycling infrastructure, regulation of tourist arrivals, etc. An excellent example of green transportation innovation is Werfenweng in Austria. Werfenweng promotes green tourism through its "completely mobile car-free vacations". Visitors are provided free train, bus, electric vehicle or horse-drawn carriage transportation options[2]. Similarly, Soel yacht designs carbon neutral solar electric vehicles to replace fossil fuel powered boats used by resorts for airport pickups or local sightseeing[3]. In December 2013, the World Biosphere Reserve of Principe Island launched the "Water and Recycle Project". The local population and tourists are given a stainless steel "Biosphere bottle" in exchange for 50 plastic bottles. This has helped raise awareness as well as reduce plastic usage[4]. Chão do Rio in Travancinha, Portugal, is another notable example of sustainable green tourism. This farm stay offers a lodging experience in stone cottages set around a 
biological pool. Nature-friendly amenities like free bicycles, a stone tank for laundry washing, outdoor fireplace, wheelbarrows for playing, a vegetable garden and farm animals help in enriching local biodiversity[5].

\section{Conclusion}

In this study, we tried to understand the influence that ICT development may have on tourism sustainability. ICT is one of the many suggested approaches to smart specialisation. Previous studies have mostly looked into the smart specialisation of European regions. We tried to emphasise the relevance of smart specialisation in the context of tourism or small-island countries. Higher development of ICT in these countries was found to be positively correlated with demand-side tourism specialisation and sustainability indicators. Higher tourism demand was correlated with higher economic growth, but it was simultaneously associated with higher emissions. A country more dependent on tourism for its total output performed well on emissions but failed to do so on the economic front. This suggests a need for complementary growth of other industries, which can be smartly aided by ICT.

Also, protection of terrestrial and marine resources of these countries did not affect the arrival of tourists. It, however, was negatively correlated with dependence on tourism sector for the total output. Higher protection also led to higher per capita GDP as a result of the development of other sectors. The development of other sectors is essential for holistic and sustainable development. Hence, higher protection is desirable, as it does not hurt the exports due to the arrival of tourists and is conducive to the development of other sectors.

The limitation of this study is that social sustainability could not be incorporated into the framework. There are ongoing debates on the right indicators for both social and environmental sustainability. Unemployment is a widely accepted social sustainability indicator. Data on unemployment levels for all the 14 countries could not be obtained. Hence, the "triple bottom line" sustainability analysis could not be done. Also, $\mathrm{CO}_{2}$ emissions may not be the perfect indicator of environmental impact. Usage of plastic bags is ubiquitous in several island countries. More tourist inflow only exacerbates the damage from using these bags that threaten marine life and corals. Such environmental impacts are not captured in $\mathrm{CO}_{2}$ emissions.

Future research using other indicators of ICT development may be done on a similar model. Moreover, tourism countries can be compared with other resource-dependent countries like oil-producing nations or rich countries like OECD nations for a better understanding of the tourism-led growth hypothesis accompanied by smart specialisation. Additionally, countryspecific fixed effects can be incorporated to control for time-invariant characteristics of countries. Also, the impact of ICT development on the seasonality of tourism can be looked upon.

\section{Notes}

1. Island Biodiversity. Convention on Biological Diversity, available at: www.cbd.int/island (accessed 2 May 2019).

2. Werfenweng, available at: www.werfenweng.eu/EN/ (accessed 3 May 2019).

3. Soel Yachts|Solar electric boats for the ocean, available at: http://soelyachts.com/ (accessed 3 May 2019).

4. Bom Bom, available at: www.bombomprincipe.com/principe/index (accessed 3 May 2019).

5. Chao do Rio - Turismo de Aldeia - Travancinha - Portugal, available at: www.chaodorio.pt/en-gb (accessed 3 May 2019). 


\section{References}

Adamou, A. and Clerides, S. (2010), "Prospects and limits of tourism-led growth: the international evidence", Review of Economic Analysis, Vol. 2 No. 3, pp. 287-303.

Avgerou, C. (1998), "How can IT enable economic growth in developing countries?", Information Technology for Development, Vol. 8 No. 1, pp. 15-28.

Avgerou, C. (2008), "Information systems in developing countries: a critical research review", Journal of Information Technology, Vol. 23 No. 3, pp. 133-46.

Bethapudi, A. (2013), "The role of ICT in tourism industry", Journal of Applied Economics and Business, Vol. 1 No. 4, pp. 4-67.

Brau, R., Lanza, A. and Pigliaru, F. (2003), "How fast are the tourism countries growing? The crosscountry evidence", Centro Euro-Mediterraneo per i Cambiamenti Climatici (CMCC).

Brau, R., Lanza, A. and Pigliaru, F. (2007), "How fast are small tourism countries growing? Evidence from the data for 1980-2003", Tourism Economics, Vol. 13 No. 4, pp. 603-13.

Buhalis, D. (1999), "Limits of tourism development in peripheral destinations: problems and challenges", Tourism Management, Vol. 20, pp. 183-5.

Camagni, R. (2017), "Regional competitiveness: towards a concept of territorial capital", Seminal Studies in Regional and Urban Economics, Springer, Cham, pp. 115-31.

Davidson, L. and Sahli, M. (2015), "Foreign direct investment in tourism, poverty alleviation, and sustainable development: a review of the Gambian hotel sector", Journal of Sustainable Tourism, Vol. 23 No. 2, pp. 167-87, available at: https://doi.org/10.1080/09669582.2014.957210

Easterly, W. and Kraay, A. (2000), "Small states, small problems? Income, growth, and volatility in small states", World development, Vol. 28 No. 11, pp. 2013-27.

Foray, D., David, P.A. and Hall, B. (2009), "Smart specialisation - the concept", Knowledge Economists Policy Brief, Vol. 9 No. 85, pp. 1-5, available at: https://doi.org/10.1016/j.pcad.2013.03.008

Garson, G.D. (2015), Structural Equation Modeling, Statistical Associates Publishers, Asheboro, NC.

Ghura, D. and Pattillo, C. (2012), Macroeconomic Policy Frameworks for Resource-Rich Developing Countries, International Monetary Fund, Washington, DC.

Gretzel, U., Sigala, M., Xiang, Z. and Koo, C. (2015), "Smart tourism: foundations and developments", Electronic Markets, Vol. 25 No. 3, pp. 179-88, available at: https://doi.org/10.1007/s12525-015-0196-8

Hilty, L.M., Lohmann, W. and Huang, E.M. (2011), "Sustainability and ICT - an overview of the field", Notizie Di Politeia, Vol. 27 No. 104, pp. 13-28, available at: https://doi.org/10.5167/uzh-55640

Holder, J.S. (1988), "Pattern and impact of tourism on the environment of the Caribbean", Tourism Management, Vol. 9 No. 2, pp. 119-27.

Holtz-Eakin, D. and Selden, T.M. (1995), "Stoking the fires? $\mathrm{CO}_{2}$ emissions and economic growth", Journal of Public Economics, Vol. 57 No. 1, pp. 85-101.

Hooper, D., Coughlan, J. and Mullen, M. (2008), "Structural equation modelling: guidelines for determining model fit", p. 2.

Hsu, C.I. and Li, C.W. (2016), "Travel and activity choices for transit travelers at terminals with dynamic information provision", Growth and Change, Vol. 47 No. 2, pp. 296-311.

Hugo, N.C. and Nyaupane, G.P. (2016), "Poverty alleviation in third world countries through tourism development: a comparison study of Costa Rica and Icaragua".

Kozak, M. (1999), Destination Competitiveness Measurement: Analysis of Effective Factors and Indicators, European Regional Science Association Conference Papers, Dublin.

Lane, B. (2001), Sustainable Tourism: Challenges and Opportunities for Hawaii, Lecture, Honolulu.

Lanza, A. and Pigliaru, F. (2000), "Why are tourism countries small and fast-growing?", Tourism and Sustainable Economic Development, pp. 57-69, available at: https://doi.org/10.2139/ssrn.146028

McCann, P. and Ortega-Argilés, R. (2015), "Smart specialisation, regional growth and applications to European Union cohesion policy”, Regional Studies, Vol. 49 No. 8, pp. 1291-302. 
McElroy, J. and de Albuquerque, K. (1991), "Tourism styles and policy responses in the open economyclosed environment context”, Caribbean Ecology and Economics, pp. 143-65.

Mulaik, S.A. and Millsap, R.E. (2000), "Doing the four-step right", Structural Equation Modeling, Vol. 7 No. 1, pp. 36-73.

Neto, F. (2003), "A new approach to sustainable tourism development: moving beyond environmental protection", Natural Resources Forum, Vol. 27 No. 3, pp. 212-22, available at: https://doi.org/10.1111/ 1477-8947.00056

Page, S.J. and Dowling, R.K. (2002), Ecotourism, Prentice Hall, Harlow.

Park, J.-Y. and Jang, S.S. (2013), "Confused by too many choices? Choice overload in tourism", Tourism Management, Vol. 35, pp. 1-12.

Piatkowski, M. (2004), "The impact of ICT on growth in transition economies", TIGER Working Paper Series No. 59.

Rogerson, C.M. (2013), "Tourism, small firm development and empowerment in post-apartheid South Africa", Small Firms in Tourism, p. 13.

Romão, J. and Neuts, B. (2017), "Territorial capital, smart tourism specialisation and sustainable regional development: experiences from Europe", Habitat International, Vol. 68, pp. 64-74.

Romão, J. and Nijkamp, P. (2017), "Spatial-economic impacts of tourism on regional development: challenges for Europe", No. 2017_01, University of Evora, CEFAGE-UE (Portugal).

Sassi, S. and Goaied, M. (2013), "Financial development, ICT diffusion and economic growth: lessons from MENA region", Telecommunications Policy, Vol. 37 Nos 4-5, pp. 252-61.

Shanker, D. (2008), "ICT and tourism: challenges and opportunities", Proceedings of International Conference on Tourism in India-Challenges Ahead, Indian Institute of Management Kozhikode, pp. 51-8.

Telfer, D.J. and Sharpley, R. (2015), Tourism and Development in The Developing World, Routledge.

UNWTO (2017), Tourism Highlights, 2016 ed., World Tourism Organization, Madrid.

XXXX (2018), "Protected Planet Report 2018", Cambridge UK; Gland, Switzerland; and Washington, DC, USA, available at: www.unep-wcmc.org (accessed 2 May 2019).

\section{Further reading}

Cubas-Díaz, M. and Martínez Sedano, M.Á. (2017), "Measures for sustainable investment decisions and business strategy - a triple bottom line approach", Business Strategy and the Environment, available at: https://doi.org/10.1002/bse.1980

Georghiou, L., Elvira Uyarra, A., Saliba Scerri, R., Castillo, N. and Cassingena Harper, J. (2014), "Adapting smart specialisation to a micro-economy - the case of Malta", European Journal of Innovation Management, Vol. 17 No. 4, pp. 428-47, available at: https://doi.org/10.1108/EJIM-03-2014-0026

Mowforth, M. and Munt, I. (2015), Tourism and Sustainability: Development, Globalisation and New Tourism in the Third World, 4th ed., available at: https://doi.org/10.4324/9781315795348

World Tourism Organization (2015), "Tourism and the sustainable development goals", UNWTO, Madrid. 


\section{Appendix}

\section{Table Al Description of variables}

\begin{tabular}{lllc} 
Variable name & Code & Dataformat & Mean (SD) \\
\hline Mobile cellular subscriptions (per 100 people) & mobile_users & Percentage & $57.304(3.049)$ \\
Terrestrial and marine protected areas (\% of total territorial area) & Ter_mar & Percentage & $0.766(0.0789)$ \\
(International tourism, receipts (current US\$))/(GDP (current US\$)) & rcpts_by_gdp & Percentage & $24.000(0.785)$ \\
International tourism, number of arrivals & In_tour_arr & Number of arrivals (natural log) & $12.605(0.068)$ \\
GDP per capita (current US\$) & In_GDPpc & Dollars (natural log) & $9.019(0.060)$ \\
$\mathrm{CO}_{2}$ emissions (metric tons per capita) & $\mathrm{CO}_{2}$ & Millions of tons & $3.744(0.154)$
\end{tabular}

\section{Corresponding author}

Korak Bhaduri can be contacted at: korakbhaduri@gmail.com

For instructions on how to order reprints of this article, please visit our website: www.emeraldgrouppublishing.com/licensing/reprints.htm

Or contact us for further details: permissions@emeraldinsight.com 